\title{
Cross-Cultural Parameters of Scribal Politesse in the Correspondence of Arab-Muslim Officials from Early Islamic Egypt*
}

\section{Arabic writings and their cognates in early Islamic Egypt}

In an often quoted papyrus letter palaeographically assigned to the ninth century (P.AnawatiPapyrusChrétien), the abbess Maryam wrote to her correspondents in Fusțāt asking questions about their recent journey. This missive stands out for its many figures of Christian religious speech. The writer further marked her religious affiliation by drawing a cross next to the religiously unbiased opening invocation bi-sm allāh al-rahmān al-rahìm. The letter is one of the first attestations of Arabic being used in an inner-Christian milieu ${ }^{1}$ and forms one of a handful of specimens of its kind datable to the first millennium. ${ }^{2}$ These documents herald the slow development of Arabic into a lingua franca for short and long-term exchanges across religious boundaries. ${ }^{3}$

At the time when Maryam was writing, about two hundred years had passed since the first Muslim armies had set foot in Egypt. ${ }^{4}$ From the mid-seventh to the early eighth centuries, Arabic writing and writings had remained an easily monopolizable prerogative of the slim, hegemonic Arab-Muslim transregional elite operating at the highest echelons of the administration. Lower administrative functions were, in principle, delegated to members of the subordinate and still largely non-Islamized and non-Arabized local elites who functioned as intermediate bodies in the relationship between the Arab-Muslim ruling group and its subjects. ${ }^{5}$ This binary system entailed the need for institutionalized vertical communication between individuals belonging to different ethnic and cultural groups and between users of separate

\footnotetext{
* Research for this paper was based at the University of Basel under the auspices of the SNSF-sponsored project 162963 "Change and Continuities from a Christian to a Muslim Society - Egyptian Society and Economy in the 6th to 8th Centuries."

1 The earliest paleographically datable Arabic Christian letters are P.Mird 45 and 46 (Khirbat al-Mird; VIII).

2 For a survey of first millennium Arabic letters ascribable to a Christian milieu, see Potthast (2019). 3 For Egypt, Richter (2009 and 2008) has suggested that the shift from Coptic to Arabic reached its turning point in the eleventh century.

4 On the Muslim conquest of Egypt, see Schmidt's and Dar's contributions in this volume.

5 On the systemic conflict of loyalties that this administrative structure entailed, see Papaconstantinou (2015).
} 
languages. Sitting at this cultural cleavage are two overlapping but distinct scribal cultures of early Islamic Egypt. The Arab-Muslim military elite employed Arabic in everyday written communication. ${ }^{6}$ Arabic also began to take primacy in public promulgations although versions in local languages continued to be provided. The graphic distinctiveness and exclusivity of Arabic public texts entailed a symbolic articulation of the social difference between the milieu of the transregional Arab-Muslim imperial elite and that of the Greek-Byzantine Christian, Middle Persian Zoroastrian etc. regional elites. ${ }^{7}$ Arabic scribal culture was characterized not only by its distinctive script and the political prestige of its practitioners, but also by the fact that Arabic writing was practiced within a framework of recognizable formulaic and aesthetic conventions. These had deep roots in a "Semitic" tradition of the pre-Islamic Near and Middle East and were not derivatives from the politically dominant official scribal cultures of the lands the Arabs conquered. ${ }^{8}$ Whereas the public use of Arabic functioned as a symbolic demonstration of power, Arab-Muslim functionaries in Egypt and elsewhere continued to engage in more pragmatic top-down communication with local representatives in the official languages of the former Sasanian and Byzantine bureaucracy and even in local vernaculars (Greek and Coptic respectively in the case of Egypt). ${ }^{9}$ Though issued in a different language, these documents mimic the formal structure, the phraseology, and elements of the layout of coeval Arabic documents. A comparison of these "Arab-style" testimonies with their Arabic counterparts reveals that Muslim officials adapted and transformed Arabic formulaic elements in the shift from one language to another or, more precisely, from one readership to another. ${ }^{10}$

6 Webb (2016) has called into question the linguistic homogeneity of the conquerors, suggesting that the garrisoned Arabs, though probably able to understand each other, used quite different Arabic dialects in spoken communication.

7 On the use of the Arabic script as a visual symbol of authority, see Bierman (1998) 31-48, Edwards (1991), and Ettinghausen (1974).

8 On the origins and formal features of early Islamic documents, see Khan (1994), id. (2008), Diem (2008) 853-861, Grob (2010) 39-83, Sijpesteijn (2013) 222-229, Reinfandt (2015) 282-286, and Kaplony (2018) 316 and 344-354.

9 The functional interplay between Arabic, Greek, and Coptic in the chanceries of early Islamic Egypt is described by Richter (2013 and 2010); cf. Sijpesteijn (2010).

10 Not discussed in this article are bilingual Arabic/Greek protocols (see Grohmann [1924]) and documents displaying an Arab-style invocation and/or dated according to the Muslim era but otherwise not displaying formal Arabic influences e. g. Mu'āwiya I’s Greek inscriptions at Hammat Gader and the Syriac graffiti at Kamed. 


\section{Formulaic features of "Arab-style" Greek epistolography}

Early Islamic Arabic official writs first became tangible through the papyrus findings in Egypt and Syria. The structure of the oldest exemplars, dating back to the seventh and eighth centuries, is characterized by a distinctive prescript.

Virtually all Arab-Muslim ${ }^{11}$ letters open with (A 1) ${ }^{12}$ the invocation bi-sm allāh alraḥmān al-rahīm (so-called basmala) usually translated as "In the name of God the Merciful, the Compassionate." The full invocation contains both allāh and al-rah$m \bar{a} n$, two common theonyms for a monotheistic God in pre-Islamic late antiquity in Arabia. ${ }^{13}$ Al-rahim is possibly a further explicative apposition of al-rahmān. ${ }^{14}$ The invocation is followed by (A 2) the address following the format min fulān ila fulān "from N.N. to N.N." and (A 3) the salutation salām 'alay-ka/-kum "peace be upon you," which is omitted if the letter is addressed to Christians. ${ }^{15}$ The salutation is followed by the benediction consisting of (A 4a 1) the hamdala (a paraphrase of Qur'an 1:2) ahmadu ilay-ka allāh ... "I praise God for your sake ..." and (A 4a 2) the first segment of the shahāda, the Muslim proclamation of faith (Q 59:22-23) ... alladhì lā ilāh illā huwa “... there is no god but He.” Arabic letters addressed to Christians drop (A 4b) the ilay-ka from the benediction. The Arabic prescript ends with (A 5) the transition formula ammā ba' $d$ "as for after" opening the main body of the letter. Arabic letters usually end with (A 6a) the valediction wa-l-salām 'alay-ka/'alaykum (Q 6:54; 7:46; 13:24; 16:32; 28:55; 39:73) wa-rạmmat allāh (Q 11:73) "peace and God's compassion be upon you" when addressed to Muslims or with (A $6 \mathbf{b}$ ) alsalām 'alā man ittaba' a al-hudā (Q 20:47) "peace be upon who follows the Guidance" in the case of Christian addressees. Finally, official letters contain a (A 7) scribal note following the format wa-kataba "has written" followed by the scribe's name and a date according to the Muslim era.

Christian civil officials serving under the aegis of Muslim rule in the seventh century continued to issue documents according to Byzantine conventions and their cor-

11 Arabic documents from the ninth century or later, written by Christians and Jews, open with a modified version of the basmala e.g. bi-sm al-āb al-ibn wa-rūh al-quds "In the name of the Father, of the Son, and of the Holy Ghost"; see Almbladh (2010) and Potthast (2019).

12 Abbreviated capital letters indicate a document's typology, Arabic Epistolography (A), Arabic Coinage (AC), and Arab-style documents (AS) respectively. Letters following the hyphen indicate the language of Arab-style documents, Greek (Gr.), Sogdian (Sg.), Middle Persian (MP), Bactrian (Bc.), and Latin (Lt.) respectively. Arabic numerals indicate the relative position of a formula.

13 On theonyms in the Qur'an, see Böwering (2002) 316a-319a, s.v. "God and His attributes" and Kaplony (2018) 321-323. On al-rạ̣mān (South Arabic rḥmnn) in particular, see Robin (2015) 153171, Nebes (2010) 35-40, and Kaplony (2018) 321; cf. Crone (2010) 166-169.

14 Ambros/Procházka (2004) 305.

15 Cf. below AS-Gr. 4 and n. 27. 
respondence lacks the distinctive features of coeval Arabic documents. ${ }^{16}$ But the Greek and bilingual letters sent by Muslim officials to their Christian subordinates in seventh- and eighth-century Syria and Egypt - whether alone or accompanied by Arabic versions ${ }^{17}$ - are quite different: their writers adhered closely to the formal typology of official Arabic letters. They open with (AS-Gr. 1a) the invocation en onomati tou theou "in God's name" or (AS-Gr. 1b) en onomati tou theou tou pantokratoros $^{18}$ "in the name of God, the Almighty." Both invocations are used in documents issued by the chanceries of governors or dukes. Documents issued by the chanceries of pagarchs customarily use the invocation syn theo "with God" instead. ${ }^{19}$ The invocation is followed by the (AS-Gr. 2) address in the format N.N. to N.N., (AS-Gr. 3) the salutation eirēne soi $^{20}$ or hymin" "peace to you" (AS-Gr. 4) the benediction eucharistoumen or eucharistō tō theō "we/I thank God" and (AS-Gr. 5a) the transition element kai meta tauta (in Egypt) or (AS-Gr. 5b) epeita (in Syria) "and afterwards." At the closing, (AS-Gr. 6a) the greeting eirēne soi/hymin ${ }^{22}$ is repeated and in some letters expanded with (AS-Gr. 6b) the addition apo tou theou ${ }^{23}$ which is probably intended to reflect the Arabic wa-rahmat allāh. ${ }^{24}$ The salutation and valediction, in particular, are invariably omitted from the Arab-style letters in Greek sent by the governor of Egypt Qurra b. Sharì (in office 709-714) to the pagarch Basileios between 709 and 711. Greek Arab-style letters often contain the (AS-Gr. 7) scribal note egraphe "it was written" and a date according to the indiction year or both the indiction year and the Hijrī year. ${ }^{25}$

16 Luiselli (2008) 696. For a collection of early Islamic Greek letters by Christian officials lacking the Arab-style prescript, see Luiselli (2008) n. 127.

17 It is generally assumed that Greek letters dispatched to Christian officials were paired with a more "representative" Arabic copy. This was first hypothesized by Bell (1910) XLII, who also suggested a number of pairs (P.Lond. IV 1349 and P.Heid.Arab. I 1, P.Lond. IV 1359 or 1345 and P.BeckerPAF 3, and P.Lond. IV and P.BeckerPAF 3 frag. 4). The Greek and Arabic missives, however, differ markedly in wording; see Richter (2010) 214.

18 P.Ness. 63.5 (Nessana; 675); P.Ness. 71.r 1 (Nessana; late VII); P.Ness. 72.1 (Nessana; 684); P.Ness.73.1 (Nessana; 683) (restored by the editor); P.Ross.Georg. V 11.r 1 (origin unknown/Egypt; VIII) (Fr. 1 pantogradoros), PSI XV 1570 (Edfu; 712).

19 Morelli (2001) 53-54.

20 SB I 4826.r 1 (Fayyūm; VII); SB VIII 9748.r 1 (Fayyūm; VII); SB VIII 9752.r 1 (Fayyūm; VII) (reconstructed by the editor).

21 PSI XV 1570.r 3 (Edfu; 712).

22 P.Apoll. 5.3 (Edfu; VII-VIII) (eirēnē hymin); P.Apoll. 8.r 5 (Edfu; VII-VIII) (eirēnē soi); P.Ness. 70.r 9 (Nessana; 685) (eirēnē soi); P.Ness. 74.r 10 (Nessana; 685) (eirēnē soi); PSI XV 1570.r 13 (Edfu; 712) (eirēnē hymin).

23 P.Apoll. 7.r 4 (Edfu; VII-VIII); P.Lond. V 1892; P.Ness. 68.r 6 (Nessana; 680); SB VIII 9748.r 5 (Fayyūm; VII); a further unpublished letter (P.Vind. inv. G 44498) only contains the segment apo tou theou; see Morelli (2010a) 42.

24 Luiselli (2008) 699.

25 For an (incomplete) survey of Greek and Coptic documents dated according to the Muslim era, see Worp (1985) 109-113. An integration of the list is provided by Bagnall/Worp (2004) 300 n. 1. 
As the prescript and closing of Arab-style Greek letters are unparalleled in preIslamic Greek epistolography, ${ }^{26}$ both can be considered as innovations brought by the Arabs. ${ }^{27}$ Upon comparison, the Arabic and Arab-style Greek formularies are not identical. The Greek invocation (AS-Gr. 1a and b) is shortened and substitutes the binomial allāh and al-rahmān (A 1) with the standard Greek term for the monotheistic God, theos. The variant en onomati tou theou tou pantokratoros (AS-Gr. 1b) further introduces an element absent from the Arabic model. ${ }^{28}$ The concept of an omnipotent god is common to all Abrahamic religions and is neither specifically Muslim nor specifically Christian. The corresponding Arabic expression to the Greek pantokratōr, allāh 'alā kull shay' qadīr - though not encountered in early Islamic documentary sources - is in fact a phrase that occurs frequently in the Qur'an (e.g. Q 2:107). Given the language and the intended readership of the documents at issue, however, the immediate horizon of reference of the pantokratōr invocation would certainly have been quite different, as the epithet pantokratōr is recurrently used in the Greek versions of both the Old and New Testaments. ${ }^{29}$ The Arab-style Greek pantokratōr invocation thus introduces a term rooted in the Christian tradition but hidden behind the façade of Muslim administrative jargon. ${ }^{30}$

The Greek salutation eirēne soi/hymin (AS-Gr. 3) is closely modelled on the Arabic salām 'alay-ka/'alay-kum (A 3). It is noteworthy, however, that Arabic letters addressed to Christians omit the salutation, whereas it is occasionally found in seventhcentury Arab-style Greek letters. ${ }^{31}$

The Greek benediction (AS-Gr. 4) is shortened and religiously neutralized as it lacks the Muslim proclamation of faith (A 4a2). The omission of the only element of the formulary explicitly hinting at the Muslim - or at least strictly monotheistic - identity of the sender sites the Arab-style Greek formulary in a non-definitionalmonotheistic rather than in a specifically Islamic religious milieu.

Equally remarkable is the Greek valediction: whether in the short form eirēne soi/ hymin (AS-Gr. 6a) or in the longer variant eirēnē soi/hymin apo tou theou (AS-Gr. 6b), the Greek valediction ${ }^{32}$ is clearly modelled on the Arabic wa-l-salām 'alay-ka (A 6a) rather than on the variant reserved for Christian addressees wa-l-salām 'alā man it-

\footnotetext{
26 Luiselli (2008) 692-697.
}

27 A handful of seventh- and eigth-century Coptic letters also display formal characteristics that can be traced back to Arabic formal influences. These include the invocation hm p-ran m-p-noute "in the name of God," the salutation $t$-irēnē na-k/nē-tn "peace to you" or t-irēnē $m$-p-noute na-k "God's peace to you," the transition element mnsa nai "after this," and the valediction $t$-irēnē na-k/nē-tn "peace to you"; see Richter (2008) 763.

28 I owe to Johannes Thomann (Zurich) the ingenious suggestion that the Greek en onomati tou theou tou pantokratoros may have been intended to recreate the metrical effect of the Arabic bi-sm allāh alrạ̣mān al-rahīm.

29 On pantokratōr, see Montevecchi (1956) particularly 418-430.

30 Luiselli (2008) 698.

31 See above n. 21 and 22.

32 See above n. 23 and 24. 
taba'a al-hudā (A 6b) despite all Arab-style Greek letters being addressed to Christians. The difference between the two greetings lies not so much in their religious associative potential (both wordings transcend religious affiliations in principle) but in the cultural difference between the (Muslim) sender and the (Christian) addressee which is accentuated by the Arabic formulation. This holds true for (A 6c) the variant of the formula encountered in the letter addressed by the governor Mūsā b. Ka $\mathrm{b}$ (in office 758 -759) to the ruler of Nubia (P.HindsNubia [Qasr Ibrim; 758]) ${ }^{33}$ salām 'alā awliyā' allāh wa-ahl țā'ati-hi "peace be upon the friends of God and those who obey Him." The (A 6d) valediction on a letter sent by the governor Qurra b. Sharik to the pagarch of Ihnās concerning Qusta "the qusțāl"34 (P.GrohmannQorra-Brief [Fayyūm; 709]) wa-l-salām 'alā muḥammad al-nabiy wa-raḥmat allāh "Peace and God's Mercy be upon the Prophet Muhammad” has, in contrast, an explicitly Muslim connotation. ${ }^{35}$

In other words, while the formulaic structure of early Islamic Arabic letters to Christian officials tends to stress cultural diversity between the Muslim sender and the Christian addressee, the Arab-style Greek letters do not do so. Upon comparison, Arab-style Greek letters are, in fact, closer in formulary to Arabic missives between Arab Muslims than they are to Arabic missives dispatched to Christians. Accordingly, the religious tone of Arab-style Greek letters is non-denominational. The anti-Trinitarian shahäda (A 4a2) is omitted and the vocabulary is culturally neutralized. The dichotomy allāh and al-raḥmān (A 1) which is only meaningful in an "Arabian” cultural background is eliminated from the Greek invocation and substituted with the biblical/Abrahamic terms theos and pantokratōr (AS-Gr. 1a and b).

Arab-style Greek letters also differ from their Arabic counterparts in their appearance. Arabic official epistolography before 800 is characterized by a distinctive layout using alineae and vacats ${ }^{36}$ to divide the documents' formulaic components into graphically separate layout blocks. ${ }^{37}$ Arab-style Greek letters, on the contrary, are organized in a single continuous text block. The same difference is apparent in bilingual Arabic/Greek demand notes framed as short letters from Egypt (the so-called entagia). The Arabic invocation is separated from the rest of the text by an alinea, but the Greek one is not graphically set apart from the main body of the document. Specimens from Syria-Palestine show a closer correspondence between the layout of

33 P.HindsNubia is discussed in greater detail in Schmidt's contribution to the present volume.

34 On the office of the qustāl, see Grohmann (1964) 276-277. On the etymology of the term < Gr. augoustalis, see Kaplony apud Richter (2010) 209.

35 I would like to thank Daniel Potthast (LMU) for calling the two formulas to my attention.

36 On the graphic arrangement of Arabic papyrus letters, see Grob (2010) 187-200.

37 In official Arabic epistolography (1) the basmala, (2) the address and the salutation, (3) the benediction, and (4) the transition formula and the main body of the text are typically singled out on the layout level. In some specimens (most notably in Qurra letters), the indented last line builds a further layout block. A comprehensive study of the layout and graphic features of Arabic documents on papyrus and paper is being undertaken by the Arabic Papyrology Database research group (Munich). I am indebted to the project's members for giving me access to internal data. 
the Arabic and Greek texts, with the invocation forming a separate layout block in both. ${ }^{38}$ The same layout is apparent only in two examples we have from Egypt. ${ }^{39}$

Arab-style Greek missives from Muslim officials furthermore employ crosses ( $\Psi$ ) as beginning and end markers. ${ }^{40}$ On eighth-century documents, crosses are frequently replaced by two oblique strokes $(/ /)$ or, less frequently, by the two symbols $\boldsymbol{\epsilon}$ and $\lambda$. These are commonly used in Arabic letters and in Greek and Coptic documents issued by Muslims. Richter, however, has convincingly shown that the use of these symbols transcended religious affiliation. They were, rather, components of an epistolary etiquette also employed by Christians when addressing Muslims and even, albeit rarely, in missives between (arguably) Christian correspondents. ${ }^{41}$ The meaning of the two strokes is unknown, though they might have an antecedent in a similar item $(V /)^{42}$ used as a paragraph and end marker in Sabaic legal documents. ${ }^{43}$ The symbol // is not used consistently, however, and Greek tax demands issued by Muslim officials continue to display crosses and Christograms well into the eighth century. ${ }^{44}$ In sum, though typologically discernible from the correspondence of Christian officials, Arab-style Greek chancery writings issued in the name of Muslim administrators generally maintained the overall appearance of Byzantine documents. ${ }^{45}$ Explicit cultural affiliation with the Arab-Muslim milieu could be expressed by secondary visual markers like symbols or by the omission of crosses. This was, however, neither a mandatory nor a universal practice.

\section{Arab officials, Roman honorifics}

One particular aspect of how Arab-style Greek documents differed from the canons of Arabic epistolography pertains to the way Arab-Muslim officials are introduced and addressed in their Greek missives. On Arabic documents, the sender is common-

38 P.Ness. 60 - 67 (Nessana; all dated between 674 and 690).

39 P.Heid.Arab. I h and P.Heid.Arab. I f = SB I 5649 (Ishqawh; 709-710).

40 As indicative examples, see SB XX 14443 (Ahnās; 643) issued in the name of 'Amr b. al-'Āṣ, CPR VIII 78 (origin unknown/Egypt; VII-VIII) issued in the name of 'Ațiya b. Ju'ayd and P.StoezerSteuerquittung (Ushmūn/Hermopolis; 694 or 709) issued in the name of Sufyān b. Ghunaym.

41 Richter (2003) 223-230.

42 On this symbol, see Stein (2010) 31.

43 The three slanting strokes used as paragraph marker in P.Cair.Arab. 39.27 (Egypt; 878), for instance, are strikingly resemblant of the one used in Sabaic documents; cf. e.g. X.BSB 107 (origin unknown; V).

44 Examples of eighth-century Greek documents issued in the name of Arab officials and displaying crosses and/or Christograms are CPR XIX 27 (Fayyūm; 730 - 750) from the chancery of Nājid b. Muslim (in office c. 730 - 750) and SPP III 260 (Medīnat al-Fayyūm; 753) from the chancery of Yahyyā b. Hilāl (in office 745-761?). On Nājid, see in particular Sijpesteijn (2013) 124-136. On Yahyā, see Gonis (2004) $189-192$ and Worp (1984) 103-107.

45 This is not peculiar to papyrological documents. The Greek inscription of Mu'āwiya I mentioned above also opens with a cross; see di Segni (1997) n. 54. 
ly introduced by name and patronymic and his official function is mentioned only rarely. ${ }^{46}$ In Arab-style Greek letters, in contrast, senders often give their names and titles (as was customary in the Byzantine tradition) or their names, patronymics, and titles. ${ }^{47}$

Titles borne by Arab officials in Greek and Coptic documents from Egypt can be borrowed from the Arabic e.g. amira/amiras ${ }^{48}$ or translated from Arabic e.g. epikeimenos pagarchias (< Arab. șāhib al-kūra). ${ }^{49}$ Some others are newly coined terms such as in the case of the Greek title of the Islamic governors, symboulos. ${ }^{50}$ Many more, however, have deeper roots in local practices. Noteworthy in this regard is the resilience of Roman honorifics in Greek and Coptic documents issued under Islamic rule, although they were now used more abitrarily than in the Byzantine period. ${ }^{51}$ The most blatant such example is the adoption of the Roman gentilitium turned honorific "Flavius." 52 The two Arab officials Flavius Atias, son of Goedos ('Atiya b. Ju'ayd), ${ }^{53}$ and Flavius Ioseph, son of Abeid (Yūsuf b. 'Ubayd), are known to bear it in Greek and Coptic documents issued by their respective chanceries. Other indirect evidence for the use of the same gentilitium by Arab officials comes from two Coptic documents mentioning one Flavius Saal, son of Abdella (Sahl b. 'Abd Allāh). ${ }^{54}$ The adoption of a Roman gentilitium by Arab Muslims allows us to infer that the connotations of Byzantine usages had survived despite their original referential dimension having disappeared. The different use of titles in Arabic and Arab-style documents also bears witness to the existence of a janiform system of social etiquette: translations and borrowings of Roman honorifics are never found in coeval Arabic letters. Only when writing in Greek (and/or Coptic) did Muslim officials "pose" as Byzantine aristocrats. ${ }^{55}$ A close parallel is provided by the use of the title pērō "victorious" on

46 Notable exceptions to this rule are the entagia of the governor 'Abd al-'Azīz b. Marwān in which the issuing authority is introduced by name and patronym as well as by title both in the Arabic ('abd al- 'aziz b. marwān al-amīr) and Greek (abdelaziz uios marouan symboulos) versions. A survey of the entagia issued in the name of 'Abd al-'Aziz is provided by Delattre et al. (2013) 364-365 and Delattre/ Vanthieghem (2016) 119.

47 This discrepancy is already apparent in the Arabic and Greek versions of the pre-Islamic bilingual inscription of Harrān, see Kaplony (2016) 391.

48 On the use of amira/amiras in Greek and Coptic documents, see Morelli (2010b) 161-162 and Sijpesteijn (2013) 117-120.

49 Gonis (2004) 190.

50 On symboulos and its origin, see Morelli (2010b) passim.

51 Papaconstantinou (2009) 452- 454.

52 On the use of Flavius as a Roman-Byzantine honorific, see Keenan (1973) and Keenan (1974).

53 On "Flavius Atias" and his archive, see Sijpesteijn/Worp (1983) 189-197, Cromwell (2013), Sijpesteijn (2013) 201-202, and Legendre (2016) 11-15.

54 On the use of Flavius in Islamic times, see Sijpesteijn (2013) 202; Papaconstantinou (2009) 453454, and Gonis/Morelli (2000) 194.

55 This does not apply to the caliph, who is only incidentally referred to with a Greek title (prōtosymboulos) in one papyrus (CPR VIII 82) and - pace Crone/Hinds (1986) - is otherwise always mentioned 
Arab-Sasanian ${ }^{56}$ coins minted in the former Sasanian territories. In the Sasanian ceremonial, the title pērō $z$ was reserved for the Sasanian Kings of Kings; it is attested in the coinage of Kavād II and Visthām. But on coins minted in Islamic times, perōz is used in an attributive sense for Arab governors. ${ }^{57}$ At the other end of the spectrum, non-Arabs could also be addressed with figures of speech usually reserved for Muslims. When the Muslim official Yazīd b. Aslam sent a letter (CPR XVI 4 [Ihnās; VIII]) to his colleague, the scribe Petosiris ${ }^{58}$, he employed a hybrid formulary. In this missive, the benediction lacks the ilay-ka (A 4b) which was customary in letters addressed to Christians. ${ }^{59}$ Yet unlike standard Arabic missives to Christian addressees, Yazìd's letter contains the salutation and the valediction generally reserved for Muslims (A 3 and A 6a). A similar case is attested by P.Jahn 12 = Chrest.Khoury I 98 (Fayyūm; VIII) in which one Umm al-Ḥakam writes to the Copt Mēnas Pekosh. Here, again, the benediction drops the ilay-ka, but the salutation and valediction generally reserved for Muslims (al-salām 'alay-ka) are used. It seems that unlike the pagarch Basileios, who had not yet mastered Arabic upon receiving Qurra's Arabic letters, the late eighth-century Copts Petosiris and Mēnas had gained mastery of the language of dominion and consequently enjoyed higher social recognition.

\section{Parallel epistolographic traditions: The "Arabic" letters from Sogdiana}

Evidence from other regions can help us contextualise these results in a broader framework. Outside Egypt and Syria, substantial bodies of documents issued by the Muslim authorities in languages other than Arabic are exceedingly rare. A precious exception is the Sogdian letter sent by the amīr 'Abd al-Raḥmān b. Șubh to the self-styled "king of Sogdia" Dēwāshtīch (706-722) and excavated in the Mount Mugh fortress in Tajikistan: Mugh 1.1 (Zarafshān; 722-723). ${ }^{60}$ The formal structure of this letter closely resembles that of Arab-style Greek epistolography. The missive

with his Arabic title whether in Arabic or Greek: Arab. 'abd allāh amīr al-mu'minīn /Gr. abdella amiralmouminin.

56 The designation “Arab-Sasanian” was introduced by Walker (1941). On the definition, see Album/ Goodwin (2002) 1.

57 Gyselen (2002) 94-95. For the possible use of pērōz as a personal name in Arab-Sasanian numismatics, see Gyselen (2002) 72.

58 On the figure of Petosiris and on phenomena of cultural brokerage in early Islamic Egypt, see Reinfandt's contribution in this volume.

59 See above (A 4b).

60 On the archaeological context of the discovery and the edition history of the document, see Livshits (2015) 15-16 and Yakubovich (2002) 232-234. 
opens with (AS-Sg. 1) the invocation "in the Name of God, the centre of creation"61 followed by the address (AS-Sg. 2) and the (AS-Sg. 3) benediction "honor/thanks to God" rendering the Arabic basmala (A 1) and hamdala (A 4a) respectively. Unlike its Greek counterparts, the Sogdian letter contains no transition formula linking the prescript to the body of the letter, and the loss of the lower part makes it impossible to ascertain the presence of the valediction and scribal note. Significantly, Mugh 1.l's formal structure differs markedly from that of the other Sogdian letters from the same archive which do not display an introductory invocation and open with an address and an endophoric reference to the type of the missive (e.g. "a report/a message" etc.). ${ }^{62}$

As regards the phraseology, a tendency towards the employment of non-denominational figures of religious speech with a connection to the local tradition can be noticed. The invocation "in the name of god, the creator" ${ }^{33}$ ( $p r n$ 'm $\beta y y^{64} \delta^{\prime} m \delta n^{\prime} k$ ) (ASSg. 1) distances itself from the Arabic basmala (A 1). The epithet $\delta$ ' $m \delta n^{\prime} k$ "creator," "centre of creation" in particular, corresponds to the Middle Persian dādār 65 "creator," one of the most recurrent attributes and theonyms of Ahura Mazdā in Zoroastrian literature. ${ }^{66}$ The Middle Persian invocation pad nām $\bar{\imath}$ dādār "in the name of the creator" is, in fact, a recurrent opening formula in Zoroastrian texts preserved in Middle Persian. ${ }^{67}$ Due to the omission of the Muslim shahāda (A 4a2), the religious constellation of the formulary remains, moreover, vaguely monotheistic. In contrast to most Arab-style Greek letters, Mugh 1.1 is clearly influenced by Arabic epistolography in its layout. In most specimens of Sogdian letters from Dēwāshtīch's archive, the text appears in a continuous rectangular layout block. In four exemplars, ${ }^{68}$ the second part of the address and the following line are inset so that they are visually distinguishable from the opening of the missive. In Mugh 1.1, on the contrary, the initial invocation builds a layout block graphically separate from the main body of the letter. ${ }^{69}$ Another Sogdian letter from the same archive issued in the name of Sa'id b. 'Abd al-'Azīz, governor ( $x m^{\prime} y r$ < Arab. amīr) of Khurāsān from 720 to 721, and ad-

61 The translation is based on the latest reedition of the text by Sims-Williams apud Livshits (2015); cf. Henning (1965).

62 For the other documents belonging to Dēwāshtīch's archive, see Livshits (2015) 52-53.

63 Translation according to Yakubovich (2002); see also Henning (1965) 249.

64 On the use of $\beta y^{-}$, lit. "lord," as a theonym in Sogdian documents, see Henning (1965). Cf. Bailey et al. (1989) 401a-403b, s.v. "Baga."

65 Cf. also Bud. Sog. $\delta^{\prime} m \delta^{\prime} r^{\prime} k$ "creator," "master of creation” used as a eulogy in Sogdian Buddhist texts; see TSP 8: 61, 71, 75, and 190 and TSP 8 bis: 5 and 9.

66 Boyce (1985) 685a and Nyberg (1974) 60, s.v. "dātār"; cf. Kellens (1989).

67 Nyberg (1964) 1 and 18. The rarer variant pad nām ì dādār weh abzōnig "in the name of the Creator, the Beneficent, the Bountiful" is probably a rendering of the complete Arabic invocation bi-sm allāh al-rahmmām al-rahīm; see Nyberg (1974) 26.

68 Mugh A-14; Mugh Nov. 2; Mugh B-16 and Mugh B-15 (all undated).

69 Livshit (2015) 90, fig. 24. 
dressed to one $w x s h w$-(...), ${ }^{70}$ the "chief priest of Samarkand," also opens with the invocation $p r n^{\prime} m \beta y y \delta^{\prime} m \delta n^{\prime} k^{71}$ The first line of the missive is broken by a lacuna after the invocation, but the remaining part of the address on the second line suggests that the invocation and address were separated by an alinea as in Mugh 1.1. The document was used to line a dagger's scabbard, and it is in a very poor state of preservation. The many lacunae hinder attempts to ascertain the presence or absence of other Arab-style formulaic features as well as further consideration of the document's layout.

A few years beforehand, the same Dēwāshtīch had addressed an Arabic petition (P.Krachiovsky [Zarafshān/717-719]) to the amīr Jarrāḥ b. 'Abd Allāh (in office 717719). ${ }^{72}$ The phraseology reveals some divergences from the Sogdian Arab-style missive described above. Unlike in Mugh 1.1, Dēwāshtīch is not introduced with his royal title "King of Sogdia and ruler of Samarkand" but styles himself "mawlā (lit. "client") of the amīr" instead. More notably, in P.Krachiovsky, the benediction includes the Muslim proclamation of faith (lines 4-5) signalizing Dēwāshtīch's recognition - at least de iure - of Islam. ${ }^{73}$ This indicates that the omission of the shahāda in Mugh 1.1 does not mark a religious parameter stricto sensu but is an element of epistolary civility. Conversely, by issuing a petition in Arabic and adopting a Muslim habitus, Dēwāshtīch placed himself - albeit in a lower position ${ }^{74}$ - in the same cultural milieu as his patron Jarrāh, whose favors he was beseeching.

\section{Parallel scribal traditions: numismatics}

\section{A) Pre-reform coinage (632-696)}

Officially sponsored Arab-style textual sources from outside Egypt are almost entirely supplied by the field of numismatics. For the first 60 years of Islamic rule, Arab numismatics mimicked Byzantine and Sasanian traditions, following their formal conventions and general appearance and using the official languages of the Byzantine and Sasanian bureaucracies. ${ }^{75}$ From 651 onwards, Arabic legends are encoun-

70 The second part of the name is unreadable.

71 The text is edited by Livshit (1962) 221. An image of the document is provided by Livshit (2015) 204-205.

72 On Dēwāshtīch’s political manoeuvering, see Yakubovich (2002).

73 It is worth mentioning that Sogdian coins issued in Panjikent during Dēwāshtīch's rule contain invocations of the local goddess "Nana, Lady of Panj." Grenet (1989) 176 and n. 34. For the interpretation of Nana as a goddess, see Henning (1965) 252 and n. 67 and 68.

74 The lower social standing of Dēwāshtīch in P.Krachiovsky is indicated not only by the generally rather humble tone of the missive and the qualification "client of the amir" but also by the positioning of the sender's name after the addressee's one (line 2).

75 For a synoptic overview of the main phases of early Islamic numismatics, see Album/Goodwin (2002) 4-34 and 77-98 and Heidemann (2009) 151-169. 
tered with increasing frequency on Arab-Sasanian coinage both as validating marks concerning the quality of the coin, and in short religious invocations. Here, Arabic and Pahlavi legends build two independent components of the coins' formulary and are not mutual translations. From the 660s-670s on, Arab-Byzantine copper coinage minted in Greater Syria (so-called "Umayyad imperial coinage") ${ }^{76}$ displays bilingual Arabic/Greek legends consisting of validating marks and mint-names. When more elaborate Arabic invocations appear, they are not accompanied by Greek translations. ${ }^{77}$

A Middle Persian rendering of the basmala in Pahlavi characters pad nām $\bar{y}$ yazdt "in the name of God" (AS-MP. 1) can be seen on a bilingual Arabic/Middle Persian weight $^{78}$ and possibly on standing-caliph ${ }^{79}$ coppers from the mint of Susa. $^{80}$ The same invocation is attested in a number of eighth-century Middle Persian documents from the so-called "Pahlavi archive" 81 as well as in an early Islamic Middle Persian letter on papyrus. ${ }^{82}$ The Bactrian equivalent of the formula pido namo iezid-aso "In the name of God" (AS-Bc. 1) ${ }^{83}$ is used in BD I Y (Balkh; 771-772) ${ }^{84}$ a Bactrian edict from the bilingual Bactrian-Arabic archive of family of Bēk ${ }^{85}$ issued by a local Turkish ruler. The Middle Persian and Bactrian rendering of the basmala parallels the Greek en onomati tou theou (AS-Gr. 1a) in that it expunges the distinctive binomial allāh/al-

76 For the definition of "Umayyad imperial coinage," see Album/Goodwin (2002) 74-75 and Goodwin (2012) 186. For an overview of the divergent terminology used by scholars to refer to the different phases of Islamic transitional coinage, see Schulze/Oddy (2012) 187-193.

77 Such is the case e.g. of the al-wafä' li-l-lāh "obeisance belongs to God" coins. On these coins, see Foss (2008) 35 and Milstein (1988-1989).

78 Curiel/Gignoux (1976) 165-169.

79 On the definition "standing-caliph," see Album/Goodwin (2002) 74 and Schulze/Oddy (2012) 193. 80 Gyselen (2000) 98, ASCC 40, and Treadwell (2008) 360 and n. 113. Based on the readings of Humbach (1966) 60 and (1967) 47 and contra Göbl (1967), the Pahlavi legends of a number (n. 211-216 and 244) of early Islamic Hunnic coin-emissions also feature the invocation PWN SHM' ZY yazdt = pat nām $\bar{\imath}$ yazdt "In the name of God," influenced by the Arabic bi-sm allăh. The readings are, however, doubtful.

81 Weber (2008).

82 Weber (2005).

83 The invocation pido namo iezid-aso is not used in any other document from the same archive whether of legal, private, or literary pertinence; it reflects, rather, the influence of the Arabic basmala; see Sims-Williams (2007) 217, s.v. iezid-.

84 On the era used in the Bactrian documents (starting point $223 \mathrm{CE}$ ) from the archive, see de Blois (2006) and Sims-Williams/de Blois (2018).

85 The circumstances of the finding and acquisition of the Bēk family archive are obscure. From internal references, one can deduce that the archive was located in the area of Balkh. On this topic, see Sims-Williams/de Blois (2018) 12-13 and Khan (2007) 14-19. The Bactrian materials (about 150 documents/BD I and II) are mostly private legal documents and letters, plus a number of accounts and a handful of Buddhist literary texts. The oldest dated items reach as far back as the fourth century, while the most recent ones stretch into the late eighth century. The Arabic documents (33 documents/P.Khurasan and Khan [2008] fig. 7.2) fall into the timespan 755-777 and are (mostly) tax receipts and assorted legal documents. 
rahmmān (A 1) of the Arabic original in favor of the more locally rooted yazd "god." "86 Furthermore, the Middle Persian translation of the basmala is reminiscent of the formula pad nām $\bar{l}$ yazdān "in the name of the gods" encountered in the third century Mazdean Middle Persian inscription of Paikuli ${ }^{87}$ and in the fourth-century Zoroastrian inscription of Meshkinshahr. ${ }^{88}$ The resemblance between the two legends induced Gignoux to postulate a Persian origin of the Muslim invocation. ${ }^{89}$ In the light of the evidence shown in this paper, one can tentatively assume that precisely the opposite is the case: that the Persian translation of the Arabic basmala may have been modelled to resemble formulaic usages rooted in local tradition. ${ }^{90}$

\section{B) Post-reform coinage}

The reform of the caliph 'Abd al-Malik in the year 77/696-697 gave Islamic numismatics its definitive form alongside its standard formulary consisting of Qur'anic paraphrases. The obverse side of reformed gold coinage displays the full proclamation of faith embracing the central legend (AC 1) lā ilāh illā allāh waḥda-hu lā sharīk la-hu "there is no god but God alone, He has no associate" and the marginal legend (AC 2) muḥammad rasūl allāh (Q 48:9) arsala-hu bi-l-hudā wa-dīn al-ḥaqq li-yuzhira-hu 'alā al-dīn kulli-hi (Q 48:28) "Muhammad is God's Messenger, He has sent Him with the guidance and the religion of truth so that He may proclaim it above all religions." "91 The reverse displays (AC 3) the text of Sura al-Ikhlās (Q 112) in the central legend allāh ahad allāh al-ṣamad lam yalid wa-lam yūlad "God, One, the Eternal He does not beget nor was begotten" and the executive marginal legend (AC 4) bi-sm allāh duriba hādhā al-dīnār bi-kadhā fī sanat kadhā "in the name of God this dìnār was minted in so-and-so in the year so-and-so."

Ironically, the first recorded use of this distinctive "Arab" formulary on coinage is not found on Arabic coins. In 72/691-692, when the Second Islamic Civil War was reaching its close, the Zubayrid' ${ }^{92}$ governor of Sijistān, 'Abd al-'Azīz b. 'Abd Allāh b. 'Āmīr, minted Middle Persian coins featuring the Muslim shahāda in Pahlavi script:

86 For some examples of the use of yazd in Sasanian epigraphy, see the references in Gignoux (1972) s.v. yazd.

87 For the text of the Paikuli inscription, see Humbach/Skjærvø (1983).

88 For the text of the Meshkinshahr inscription, see Frye/Skjærvø (1996).

89 Gignoux (1979) and Gignoux/Algar (1990) 172a.

90 The basmala more probably reflects Judeo-Christian influences; see Shaked (1992) 152-153.

91 On reformed dirhams, this legend is displayed on the reverse side and encompasses the extra bit wa-law kariha al-mushrikūn "... even if the 'associators' hate it.” For the determination of the reverse side on silver reformed coinage, see Bacharach (2010) 16.

92 On the strategies of Zubayrid propaganda, see Lynch (2014) and Foss (2013); cf. Treadwell (2012). 
dōaftād

yazd-ew bē oy

any yazd nēst

Muhammad paygāmbar i yazd

SK
"Seventy-two

One God but He

Another God does not exist

Muhammad (is) the Messenger of God

SK (= Sagastān $)^{93 » "}$

These coins not only feature an ante litteram ${ }^{94}$ transposition of the complete shahāda but also embrace the all-epigraphic layout of the future reformed coinage. Even the disposition of the legends heralds the layout of the all-epigraphic coinage whereby the administrative information encloses the field legend.

Gradually, the new all-epigraphic Arabic coins supplanted Arab-Byzantine and Arab-Sasanian emissions throughout the empire. Latin coins minted at the western edge of the Muslim Empire in North Africa and Spain between c. 698 and 716 are exceptional in this respect, as they organically combine translations of the Arab formulary with elements of pre-reform coinage. This hybrid nature is apparent already on visual grounds: gold emissions minted at the newly established main North African mint ${ }^{95}$ are entirely epigraphic, following the model of the reformed Syrian series. The mint of the old Byzantine regional capital of Carthage, on the contrary, minted image-based gold coins with Byzantine iconography. ${ }^{96}$

Arab-Byzantine Latin coinage has a few remarkable features. The arrangement of the legends is distinctive, to begin with: in Arabic reformed coinage, the basmala and shahāda are not part of the same legend, but on Muslim Latin coinage, they often appear together. As regards the legends themselves, renderings of the basmala (A 1) range from relatively faithful ones like (AS-Lt. 1a):

in nomine domini misericordis

"In the name of the Merciful Lord/In the name of the Lord, the Merciful"

to unparalleled reformulations such as (AS-Lt. 1b):

in nomine tuo deus vivificans et misericors

"In Thy name, o life-giving and merciful God"

93 The first specimen of this kind was published by Mochiri (1981) from whom I reproduce both the Middle Persian text and the translation; Mochiri (1981) translates "doesn't."

94 The Pahlavi epigraphic issues of 'Abd al-'Aziz b. 'Abd Allāh b. 'Āmīr postdate by a year the earliest attestation of (a version of) the profession of faith found on a Arabic tombstone from Aswan, and are contemporary to the versions of the shahāda included in the Arabic legends of imitative Byzantine solidi and on the so-called "standing-caliph" gold coinage minted in Damascus, as well as in the mosaics of the Dome of the Rock in Jerusalem. On the earliest versions of the shahäda, see Bacharach/ Anwar (2012).

95 It is debated whether the main North African mint was an urban one or an itinerant mint; see Jonson (2015) 219.

96 Bates (1995) 13. 
The same holds true for renderings of the shahāda. Some adhere very closely to the Arabic model, among them the legend (AS-Lt. 2a):

non est deus nisi ipse solus cui socius non est

"There is no God but He (Himself) alone, Who has no associate"

or slight variations thereof. Parallel, freer reformulations of the profession of faith, however, are also very common such as (AS-Lt. 2b):

non deus nisi deus omnium creator

"There is no God but God, the Creator of all things"

Finally, some of the Latin phraseology is almost entirely unrelated in wording to the original Arabic model. This is the case in invocations like (AS-Lt. 0a):

deus eternus deus magnus omnium creator

"God the Eternal, God the Great, the Creator of all things"

or (AS-Lt. Ob):

deus dominus noster magnus eternus omnia noscens

"God our Lord, the Wise, the Great, the Eternal, the All-knowing"

and (AS-Lt. Oc):

Deus tuus Deus

"Your god is God"

The array of theonyms and divine attributes used on Arab-Byzantine Latin coinage has parallels in both biblical and Qur'anic usage. ${ }^{97}$ For cultural and linguistic reasons, however, biblical vocabulary would have been much more recognizable to local users of the coins. Furthermore, biblical references go beyond terminological affinities. In fact, some of the Latin invocations which have no parallel in the Arabic model phraseology echo passages of the Latin Vulgata. The invocation in nomine tuo for instance is found in several passages in the Old and New Testaments, ${ }^{98}$ but has only extra-Qur'anic Arabic parallels and never occurs on Arabic coinage. ${ }^{99}$ Deus tuus Deus (AS-Lt. 0c) echoes Deuteronomy 7:9 Deus tuus ipse est Deus. One of the legends in particular, (AS-Lt. Od) Dominus quis tibi similis, is a verbatim quote from the

97 A list of the Qur'anic parallels to the theonyms and attributes used in Islamic Latin coinage is provided by Walker (1956) C.

98 E.g. in Ps 43:9, Ps 53:3, Ps 88:17, Ps 115:17, etc., and in Mt 7:22 etc.

99 The reported text of the treaty of Hudaybiya opens with the invocation bi-smi-ka allāhumma "in Thy name, oh God." On Muslim traditions pertaining to the treaty, see Wensinck (1927) 102a-b, s.v. "Hudaibiya." 
Psalms. ${ }^{100}$ In addition, the second part of the shahāda proclaiming Muhammad's prophetic mission (AC 2) and the markedly anti-Christian Sura al-Ikhlāṣ (AC 3) are the only legends of the Arabic formulary which are never once referenced in the Latin version(s). ${ }^{101}$

Commenting on the Islamic Latin coinage from North Africa, Bates discusses "the difficulty that these provincial early Muslims had in composing an adequate version of the Muslim shahäda" and ascribes these difficulties to the remoteness of the region from the imperial capital in Damascus. ${ }^{102}$ While a comprehensive explanation for the high degree of variations in the Latin formulary of Islamic coins from the Maghreb is yet to be provided, the adaptations of Muslim phraseology must be contextualized within the broader trend attested in different regions of the Islamic Empire. Like other corpora of Arab-style documents, Latin adaptations of the shahā$d a$ (AS-Lt. 2a and b) and basmala (AS-Lt. 1a and b) use the omission or re-elaboration of explicitly Muslim-Arab elements to create an ambiguous or rather ambivalent transcultural non-definitional monotheistic framework.

\section{Concluding remarks}

The shifting parameters of social behavior evidenced in this contribution place themselves at the confluence of the Arab-Muslim elite's need to stress its exclusive cultural traits, on the one hand, and to deploy effective communicative strategies, on the other. Much like their Arabic counterparts, Arab-style documents were the prerogative of Arab-Muslim officials and used their formal structure and, to a lesser extent, their aesthetic appearance to convey an impression of authority to their recipients. Whereas the Arabic writings of Arab-Muslim officials from early Islamic Egypt stressed specific Arab-Muslim cultural traits by means of language, formulary, and even layout, their Arab-style Greek correspondence shares not only a common language but also a common non-denominational religious language and common parameters of scribal politesse with pre-Islamic Greek epistolography. This institutionalized practice of cultural ambivalence is not to be read as a statement of cultural identity but as a form of negotiation and communicative civility. The comparison with documents from Syria, North Africa, and Khurāsān further reveals that, despite adjustments to the specific regional contexts, the social behavior of the Arab-Muslim ruling group towards the local Christian elite in Egypt aligned with a more general attitude towards the non-Muslim regional elites of the empire. For members of the Arab-Muslim imperial elite confronted with a largely non-Arabicized and non-Islamicized social environment, negotiating the most divisive aspects of their cultural iden-

100 Ps 44:10, Ps 70:19, Ps 82:2, and Ps 88:9.

101 In bilingual Latin-Arabic issues minted between 716 and 719, the Muhammad formula is only in the Arabic text, see Bates (1992); BMC II n. 184-J. 6; Miles (1950) n. 1 (a-f).

102 Bates (1995) 15. 
tity to create more fluid channels of cross-cultural communication seems to have been an acceptable and maybe even a necessary compromise.

\section{Bibliography}

Almbladh (2010): Karin Almbladh, "The 'Basmala' in medieval letters in Arabic written by Jews and Christians", in: Orientalia Suecana 59, 45-60.

Album/Goodwin (2002): Stephen Album and Tony Goodwin, Sylloge of Islamic Coins in the Ashmolean I: The Pre-Reform Coinage of the Early Islamic Period, Oxford.

Ambros/Procházka (2004): Arne A. Ambros and Stephan Procházka, A Concise Dictionary of Koranic Arabic, Wiesbaden.

Bacharach/Anwar (2012): Jere L. Bacharach and Sherif Anwar, "Early versions of the shahäda. A tombstone from Aswan of 71 A.H., the Dome of the Rock, and contemporary coinage", in: Der Islam 89.2, 60-69.

Bacharach (2010): Jere L. Bacharach, "Signs of sovereignty. The shahāda, Qur'anic verses, and the coinage of 'Abd al-Malik", in: Muqarnas 27, 1-30.

Bagnall/Worp (2004): Roger S. Bagnall and Klaas A. Worp, Chronological Systems of Byzantine Egypt, $2^{\text {nd }}$ ed., Leiden.

Bailey et al. (1989): Harold W. Bailey, Nicholas Sims-Williams, and Stefan Zimmer, "Baga", in: Encyclopaedia Iranica, vol. III, 401a-406a.

Bates (1992): Michael L. Bates, "The coinage of Spain under the Umayyad caliphs of the East, 711-750”, in: Carmen A. Asíns (ed.), III Jarique de Numismática Hispano-Árabe, Museo Arqueológico Nacional, Madrid, 13-16 dicembre 1990, Madrid, 271-289.

Bates (1995): Michael L. Bates, "Roman and early Muslim coinage in North Africa”, in: Mark Horton and Thomas Wiedemann (eds.), North Africa from Antiquity to Islam. Papers of a Conference Held at Bristol, October 1994, Bristol, 12-15.

Bell (1910): Harold I. Bell, Greek Papyri in the British Museum Catalogue, with Texts, vol. IV: The Aphrodito Papyri. With an Appendix of Coptic Papyri ed. by W.E. Crum (= P.Lond. IV), London.

Bierman (1998): Irene A. Bierman, Writing Signs. The Fatimid Public Text, Berkeley, Los Angeles, and London.

de Blois (2006): François de Blois, "Du nouveau sur la chronologie bactrienne post-hellénistique. L'ère de 223-224 ap. J.-C”, in: Comptes Rendus des Séances de l'Académie des Inscriptions et Belles-Lettres 150.2, 991-997.

Boyce (1985): Mary Boyce, “Ahura Mazdā”, in: Encyclopaedia Iranica, vol. I, 684b-687b.

Böwering (2002): Gerhard Böwering, “God and His attributes”, in: Encyclopaedia of the Qur'ān, vol. II, 316b-331b.

Cromwell (2013): Jennifer Cromwell, “Coptic texts in the archive of Flavius Atias”, in: Zeitschrift für Papyrologie und Epigraphik 184, 280-288.

Crone (2010): Patricia Crone, "The religion of the Qur'ānic pagans. God and the lesser deities", in: Arabica 57, 151-200.

Crone/Hinds (1986): Patricia Crone and Martin Hinds, God's Caliph. Religious Authority in the First Centuries of Islam (University of Cambridge Oriental Publications 37), Cambridge.

Curiel/Gignoux (1976): Raôul Curiel and Philippe Gignoux, "Un poids arabo-sasanide”, in: Studia Iranica 5, 165-169.

Delattre et al. (2013): Alain Delattre, Rosario Pintaudi, and Naïm Vanthieghem, "Un entagion bilingue du gouverneur 'Abd al-'Azīz ibn Marwān trouvé à Antinoé”, in: Chronique d'Egypte 88, 363-371. 
Delattre/Vanthieghem (2016): Alain Delattre and Naïm Vanthieghem, "Un ensemble archivistique trilingue à Strasbourg. Un protocole et deux ordres de réquisition de la fin du VII siècle", in: Jean-Luc Fournet and Arietta Papaconstantinou (eds.), Mélanges Jean Gascou. Textes et études papyrologiques 1 (= P.Gascou) (Travaux et Mémoires 20.1), Paris, 109-131.

Edwards (1991): Holly Edwards, “Text, context, architext. The Qur'an as architectural inscription”, in: Carol G. Fisher (ed.), Brocade of the Pen. The Art of Islamic Writing, East Lansing, 63-75.

Ettinghausen (1974): Richard Ettinghausen, "Arabic epigraphy. Communication or symbolic affirmation?”, in: Dickran K. Kouymjian (ed.), Near Eastern Numismatics, Iconography, Epigraphy, and History. Studies in Honor of George C. Miles, Beirut, 297-317.

Foss (2008): Clive Foss, Arab-Byzantine Coins. An Introduction, with a Catalogue of the Dumbarton Oaks Collection (Dumbarton Oaks Byzantine Collection Publications 12), Washington D.C.

Foss (2013): Clive Foss, “'Abdallāh ibn al-Zubayr and his coinage”, in: Journal of the Oriental Numismatic Society 216, 11-17.

Frye/Skjærvø (1996): Richard N. Frye and Prods O. Skjærvø, "The Middle Persian inscription from Meshkinshahr", in: Bulletin of the Asia Institute 10, 53-61.

Gignoux (1972): Philippe Gignoux, Glossaire des inscriptions pehlevies et parthes (Corpus Inscriptionum Iranicum 1), London.

Gignoux (1979): Philippe Gignoux, “Pour une origine iranienne du bi’smillah”, in: Philippe Gignoux, Raôul Curiel, Rika Gyselen, and Clarisse Herrenschmidt (eds.), Pad nām I yazdān. Études d'épigraphie, de numismatique et d'histoire de l'rran ancien (Travaux de l'Institut d'études iraniennes de l'Université de la Sorbonne nouvelle 9), Paris, 159-163.

Gignoux/Algar (1990): Philippe Gignoux and Hamid A. Algar, "Besmallāh", in: Encyclopaedia Iranica, vol. IV, 172a-174a.

Göbl (1967): Robert Göbl, Dokumente zur Geschichte der iranischen Hunnen in Baktrien und Indien, vol. I, Wiesbaden.

Gonis (2004): Nikolaos Gonis, “Another look at some officials in early 'Abbāsid Egypt”, in: Zeitschrift für Papyrologie und Epigraphik 149, 189-195.

Gonis/Morelli (2000): Nikolaos Gonis and Federico Morelli, "A requisition for the "commander of the Faithful': SPP VIII 1082 Revised”, in: Zeitschrift für Papyrologie und Epigraphik 132, $193-195$.

Goodwin (2012): Tony Goodwin, "The standard terminology in SICA 1", in: Tony Goodwin (ed.), Arab Byzantine Coins and History. Papers presented at the $13^{\text {th }}$ Seventh Century Syrian Numismatic Round Table Held at Corpus Christi College, Oxford, on $11^{\text {th }}$ and $12^{\text {th }}$ September 2011, London, 185-186.

Grenet (1989): Frantz Grenet, “Les 'Hunes’ dans les documents sogdiens du mont Mugh”, in: Charles-Henri de Fouchecour and Philippe Gignoux (eds.), Études irano-aryennes offertes à Gilbert Lazard, Paris, 165-184.

Grob (2010): Eva M. Grob, Documentary Arabic Private and Business Letters on Papyrus. Form and Function, Content and Context (Archiv für Papyrusforschung und verwandte Gebiete Beiheft 29), Berlin.

Grohmann (1924): Adolf Grohmann, Protokolle (= CPR III: Series Arabica 1, 2-3), Wien.

Grohmann (1964): Adolf Grohmann, "Der Beamtenstab der arabischen Finanzverwaltung in Ägypten in früharabischer Zeit”, in: Horst Braunert (ed.), Studien zur Papyrologie und antiken Wirtschaftsgeschichte. Friedrich Oertel zum achtzigsten Geburtstag gewidmet, Bonn, $120-134$.

Gyselen (2000): Rika Gyselen, Arab-Sasanian Copper Coinage (= ASCC), Vienna.

Heidemann (2009): Stefan Heidemann, "The evolving representation of the early Islamic Empire and its religion on coin imagery", in: Angelika Neuwirth, Nicolai Sinai, and Michael Marx (eds.), The Qur'ān in Context. Historical and Literary Investigations into the Qur'ānic Milieu (Texts and Studies on the Qur'ān 6), Leiden \& Boston, 149-195. 
Henning (1965): Walter B. Henning, “A Sogdian god”, in: Bulletin of the School of Oriental and African Studies 28.2, 242-254.

Humbach (1966): Helmut Humbach, Baktrische Sprachdenkmäler. Teil I, Wiesbaden.

Humbach (1967): Helmut Humbach, "Zu den Legenden der hunnischen Münzen. Siegel und Kontermarken”, in: Münchener Studien zur Sprachwissenschaft 22, 39-56.

Humbach/Skjærvø (1983): Helmut Humbach and Prods 0. Skjærvø The Sassanian Inscription of Paikuli. Part 3.1: Restored Text and Translation, Wiesbaden.

Jonson (2015): Trent Jonson, “The earliest Islamic copper coinage of North Africa”, in: Andrew Oddy, Ingrid Schulze, and Wolfgang Schulze (eds.), Coinage and History in the Seventh Century Near East 4. Proceedings of the $14^{\text {th }}$ Seventh Century Syrian Numismatic Round Table Held at The Hives, Worcester on $28^{\text {th }}$ and $29^{\text {th }}$ September 2013, London, 217-240.

Kaplony (2016): Andreas Kaplony, "Die Arabisierung der frühislamischen Verwaltung Syrien-Palästinas und Ägyptens im Spiegel der zweisprachigen griechisch-arabischen Dokumente (550-750). Ein Plädoyer für einen regionalen Ansatz", in: Angelika Neuwirth, Nora K. Schmid, and Nora Schmidt (eds.), Denkraum Spätantike. Szenarien der Reflexion von Antiken im Umfeld des Koran (Episteme in Bewegung: Beiträge zu einer transdisziplinären Wissensgeschichte 5), Wiesbaden, 387-404.

Kaplony (2018): Andreas Kaplony, “Comparing Qur’ānic suras with pre-800 documents (with an appendix on subtypes of pre-800 kitāb documents)", in: Der Islam 95, 312-366

Keenan (1973): James G. Keenan, “The mames Flavius and Aurelius as status designations in later Roman Egypt” (part 1), in: Zeitschrift für Papyrologie und Epigraphik 11, 33-63.

Keenan (1974): James G. Keenan, "The names Flavius and Aurelius as status designations in later Roman Egypt" (part 2), in: Zeitschrift für Papyrologie und Epigraphik 13, 283-304.

Khan (1994): Geoffrey Khan, "The pre-Islamic background of Muslim legal formularies”, in: Aram Periodical 6, 193-224.

Khan (2007): Geoffrey Khan, Arabic Documents from Early Islamic Khurasan, Studies in the Khalili Collection 5 (= P.Khurasan), London.

Khan (2008): Geoffrey Khan, "Remarks on the historical background and development of the early Arabic documentary formulae”, in: Eva M. Grob and Andreas Kaplony (eds.), Documentary Letters from the Middle East. The Evidence in Greek, Coptic, South Arabian, Pehlevi, and Arabic (1 $1^{\text {st }}-15^{\text {th }}$ C CE) (Asiatische Studien 62.3), Bern et al., 885-906.

Legendre (2016): Marie Legendre, "Neither Byzantine nor Islamic? The duke of the Thebaid and the formation of the Umayyad state", in: Historical Research 89, 3-18.

Livshits (1962): Vladimir A. Livshits, Juridičeskie dokumenty i pis'ma (Sogdijskie dokumenty s gory Mug II), Moscow.

Livshits (2015): Vladimir A. Livshits, Sogdian Epigraphy of Central Asia and Semirech'e. Corpus Inscriptionum Iranicarum Part II: Inscriptions of the Seleucid and Parthian periods and of Eastern Iran and Central Asia (transl. Nicholas Sims-Williams), London.

Luiselli (2008): Raffaele Luiselli, "Greek letters on papyrus. First to eighth century. A survey", in: Eva M. Grob and Andreas Kaplony (eds.), Documentary Letters from the Middle East. The Evidence in Greek, Coptic, South Arabian, Pehlevi, and Arabic $\left(1^{\text {st }}-15^{\text {th }}\right.$ C CE) (Asiatische Studien 62.3), Bern et al., 677-737.

Lynch (2014): Ryan J. Lynch, "Sons of the Muhājirūn. Some comments on Ibn al-Zubayr and legitimizing power in seventh-century Islamic history", in: Alessandro Gnasso, Emanuele E. Intagliata, Thomas J. McMaster, and Bethan N. Morris (eds.), The Long Seventh Century. Continuity and Discontinuity in an Age of Transition, Oxford et al., 251-268.

Milstein (1988-1989): Rachel Milstein, “A hoard of early Arab figurative coins," in: Israel Numismatic Journal 10, 3-26.

Mochiri (1981): Malek I. Mochiri, “A Pahlavi forerunner of the Umayyad reformed coinage”, in: The Journal of the Royal Asiatic Society of Great Britain and Ireland 2, 168-172. 
Montevecchi (1956): Orsolina Montevecchi, “Pantokrator”, in: Edoardo Arslan (ed.), Studi in onore di Aristide Calderini e Roberto Paribeni II.2, Milan, 401-432.

Morelli (2001): Federico Morelli, Documenti greci per la fiscalità e la amministrazione dell'Egitto arabo (= CPR XXII), 2 vols., Vienna.

Morelli (2010a): Federico Morelli, L'archivio di Senouthios anystes e testi connessi. Lettere e documenti per la costruzione di una capitale ( $=$ CPR XXX), Berlin.

Morelli (2010b): Federico Morelli, “Consiglieri e comandanti. I titoli del governatore arabo d'Egitto symboulos e amîr", in: Zeitschrift für Papyrologie und Epigraphik 173, 158-166.

Nebes (2010): Norbert Nebes, "The martyrs of Najrān and the end of the Himyar. On the political history of South Arabia in the early sixth century", in: Angelika Neuwirth, Nicolai Sinai, and Michael Marx (eds.), The Qur'ān in Context. Historical and Literary Investigations into the Qur'ānic Milieu (Texts and Studies on the Qur'ān 6), Leiden, 27-59.

Nyberg (1964): Henrik S. Nyberg, A Manual of Pahlavi. Part I: Texts, Wiesbaden.

Nyberg (1974): Henrik S. Nyberg, A Manual of Pahlavi. Part II: Glossary, Wiesbaden.

Papaconstantinou (2009): Arietta Papaconstantinou, “'What remains behind'. Hellenism and Romanitas in Christian Egypt after the Arab conquest”, in: Hannah M. Cotton et al. (eds.), From Hellenism to Islam: Cultural and Linguistic Change in the Roman Near East, Cambridge, 447-466.

Papaconstantinou (2015): Arietta Papaconstantinou, "The rhetoric of power and the voice of reason. Tensions between central and local in the correspondence of Qurra ibn Sharīk", in: Stephan Procházka, Lucian Reinfandt, and Sven Tost (eds.), Official Epistolography and the Language(s) of Power. Proceedings of the First International Conference of the Research Network "Imperium \& Officium: Comparative Studies in Ancient Bureaucracy" and Officialdom, University of Vienna, 10-12 November 2010 (Papyrologica Vindobonensia 8), Vienna, 267-281.

Potthast (2019): Daniel Potthast: "Qur'ān Quotations in Arabic Papyrus Letters from the 7th to the 10th Centuries", in: Andreas Kaplony and Michael Marx (eds.), Qur'än Quotations Preserved on Papyrus Documents, 7th-10th Centuries and The Problem of Carbon Dating Early Qur'āns (Documenta Coranica 2), Leiden and Boston, 42-85.

Raghib (2013): Youssef Raghib, “Les premiers documents arabes de l'ère musulmane”, in: Constantin Zuckerman (ed.), Constructing the Seventh Century (Travaux et mémoires 17), Paris, 679-729.

Reinfandt (2015): Lucian Reinfandt, “Empireness in Arabic letter formulae”, in: Stephan Procházka, Lucian Reinfandt, and Sven Tost (eds.), Official Epistolography and the Language(s) of Power. Proceedings of the First International Conference of the Research Network "Imperium \& Officium: Comparative Studies in Ancient Bureaucracy" and Officialdom, University of Vienna, 10-12 November 2010 (Papyrologica Vindobonensia 8), Vienna, 281-292.

Richter (2003): Tonio Sebastian Richter, "Spätkoptische Rechtsurkunden neu bearbeitet (III): $P$. Lond. Copt. I 487. Arabische Pacht in koptischem Gewand", in: The Journal of Juristic Papyrology 33, 213-230.

Richter (2008): Tonio Sebastian Richter: "Coptic letters", in: Eva M. Grob and Andreas Kaplony (eds.), Documentary Letters from the Middle East. The Evidence in Greek, Coptic, South Arabian, Pehlevi, and Arabic (1 $1^{\text {st }}-15^{\text {th }}$ C CE) (Asiatische Studien 62.3), Bern et al., 739-770.

Richter (2009): Tonio Sebastian Richter, “Greek, Coptic and the 'language of the Hijra'. The rise and decline of the Coptic language in late antique and medieval Egypt", in: Hannah M. Cotton et al. (eds.), From Hellenism to Islam. Cultural and Linguistic Change in the Roman Near East, Cambridge, 401-446.

Richter (2010): Tonio Sebastian Richter, "Language choice in the Qurra dossier”, in: Arietta Papaconstantinou (ed.), The Multilingual Experience in Egypt, from the Ptolemies to the 'Abbāsids, Burlington, 189-220. 
Richter (2013): Tonio Sebastian Richter, “'An unseren Herrn, den allberühmten Korra, den herrlichsten Gouverneur, durch Dich, glorreichster Herr Basilios, Pagarch von Djkow mit seinen Gehöften'. Verwaltung und Verwaltungssprachen Ägyptens im 8. Jh. nach den Qurra-Papyri”, in: Frank Feder and Angelika Lohwasser (eds.), Ägypten und sein Umfeld in der Spätantike. Vom Regierungsantritt Diokletians 284/285 bis zur arabischen Eroberung des Vorderen Orients um 635-646. Akten der Tagung vom 7.-9.7.2011 in Münster (Phillipika 61), Wiesbaden, 121-138.

Robin (2015): Christian J. Robin, “Himyar, Aksūm, and Arabia Deserta in late antiquity”, in: Greg Fischer (ed.), Arabs and Empires before Islam, Oxford, 127-171.

Schulze/Oddy (2012): Wolfgang Schulze and Andrew Oddy, "Terminology for the transitional coinage struck in $7^{\text {th }}$ century Syria after the Arab conquest", in: Tony Goodwin (ed.), Arab Byzantine Coins and History. Papers presented at the Seventh Century Syrian Numismatic Round Table Held at Corpus Christi College, Oxford, on $10^{\text {th }}$ and $11^{\text {th }}$ September 2011, London, 187-200.

di Segni (1997): Leah di Segni, “The Greek inscriptions of Hammat Gader”, in: Yizhar Hirschfeld (ed.), The Roman Baths of Hammat Gader. Final Report, Jerusalem, 185-266.

Shaked (1992): Shaul Shaked, "Some Iranian themes in Islamic literature", in: Philippe Gignoux (ed.), Recurrent Patterns in Iranian Religions. From Mazdaism to Sufism. Proceedings of the Round Table Held in Bamberg (30 ${ }^{\text {th }}$ September- $4^{\text {th }}$ October 1991), Paris, 143-158.

Stein (2010): Peter Stein (ed.), Die altsüdarabischen Minuskelinschriften auf Holzstäbchen aus der Bayerischen Staatsbibliothek in München. Epigraphische Forschungen auf der Arabischen Halbinsel 5,2 vols. ( $=X . B S B)$, Tübingen.

Sijpesteijn/Worp (1983): Pieter J. Sijpesteijn and Klaas A. Worp (eds.), Corpus Papyrorum Raineri, Vol. VIII: Griechische Texte V (= CPR VIII), Vienna.

Sijpesteijn (2010): Petra M. Sijpesteijn, "Multilingual archives and documents in post-conquest Egypt”, in: Arietta Papaconstantinou (ed.), The Multilingual Experience in Egypt, from the Ptolemies to the 'Abbāsids, Burlington, 105-124.

Sijpesteijn (2013): Petra M. Sijpesteijn, Shaping a Muslim State. The World of a Mid-Eighth-Century Egyptian Official (Oxford Studies in Byzantium), Oxford.

Sims-Williams (2007): Nicholas Sims-Williams, Bactrian Documents from Northern Afghanistan II: Letters and Buddhist Texts (= BD II), London.

Sims-Williams/de Blois (2018): Nicholas Sims-Williams and François de Blois, Studies in the Chronology of the Bactrian Documents from Northern Afghanistan. With Contributions by Harry Falk and Dieter Weber, Vienna.

Treadwell (2008): Luke Treadwell, “The copper coinage of Umayyad Iran”, in: The Numismatic Chronicle 168, 331-381.

Walker (1941): John Walker, A Catalogue of the Muhammadan Coins in the British Museum Part 1: A Catalogue of the Arab-Sassanian Coins (Umaiyad Governors in the East, Arab-Ephthalites, 'Abbāsid Governors in Tabaristān and Buǩhāāā), London.

Wensinck (1927): Arent J. Wensinck, A Handbook of Early Muhammadan Tradition. Alphabetically Arranged, Leiden.

Worp (1984): Klaas A. Worp, “Studien zu spätgriechischen, koptischen und arabischen Papyri”, in: Bulletin de la Société d'Archéologie Copte 26, 99-108.

Worp (1985): Klaas A. Worp, “Hegira years in Greek, Greek-Coptic and Greek-Arabic papyri”, in: Aegyptus 65, 107-115.

Weber (2005): Dieter Weber, “A Pahlavi papyrus from Islamic times”, in: Bulletin of the Asia Institute 19, 225-231.

Weber (2008): Dieter Weber, "New arguments for dating the documents from the 'Pahlavi archive"', in: Bulletin of the Asia Institute 22, 215-222.

Webb (2016): Peter Webb, Imagining the Arabs. Arab Identity and the Rise of Islam, Edinburgh. 
Yakubovich (2002): Ilya Yakubovich, “Mugh 1.I revisited”, in: Studia Iranica 31.2, 231-253. 